\title{
石狩海岸平野の地形と土壤について
}

\author{
上杉陽 ${ }^{2} \cdot$ 遠 藤邦 彦3)
}

\section{On the Topographies and Soils of the Ishikari Coastal Plain}

\author{
Yo Uesugr ${ }^{21}$ and Kunihiko ENDo ${ }^{31}$
}

The purpose of this study is to discuss the geomorphic development and soil genesis mainly of the sandy area of the Ishikari coastal plain, Hokkaidô, northern Japan. To serve as an aid to this purpose, many archaeological, tephrochronological, granulometrical data are used.

The results are summerized as follows:

1) The sandy area is classified into three morphologic provinces, namely Momijiyama sand dunes, Bannaguro emerged sand bars, Ishikari sand dunes, from the inland to the coast respectively. This arrangement of each topography, such as an older dune, a sand bar and a younger dune, are generally observed in large alluvial plains in Japan. This pattern is differentiated from that of narrow coastal plains where the younger dune is piled upon the older one.

2) The soils are classified into two by the stage of formation, namely the lower dark sandy loam and the upper black humus.

3) Momijiyama sand dunes cover the pleistocene lower terrace deposits or upper tertiary formation, probably being at the depth near the present sea level.

These dunes developed on a gravel or sand bar which was formed during the maximum transgression stage of Early Jômon. The sea level of this stage reached $4 \mathrm{~m}$ or more meters above the present sea level. Before the early stage of Middle Jômon, these dunes were already transformed into the longitudinal dunes and fixed by the lower dark sandy loam. These dunes are correlated to the older sand dune definited by ENDo (1969).

4) Bannaguro emerged sand bars are the assemblage of more than twenty parallel sand bars, which consist of shallow marine deposits built during and after the maximum transgression stage. Then a large number of these sand bars were emerged and immediately fixed by the lower dark sandy loam before the later stage of Middle Jômon. Thus, wind-blown sands were deposited only on a small scale on the emerged sand bars.

5) The lower dark sandy loam is correlated to the older humus sand definited by ENDo (1969), and its formation continued at least from Middle to Later Jomon in this area. During Middle Jômon, the soil genesis was probably performed under rather warm climate, but it suffered podosolization under cool and humid climate during Latest Jômon. Thus, the lower dark sandy loam is a kind of polygenetic soils. This type of older humus sand is only observed north of this area in Japan.

6) In the early stage of Latest Jômon (3000-3500 years B. P.), peat bogs appeared at depressions between several emerged sand bars, although in the inland alluvial plain inside of Momijiyama sand dunes, the deposition of peat had already begun since $5000-6000$ years B.P..

7) The lower part of Ishikari sand dunes were formed on the marine sand beds deposited during the small transgression of possibly Satsumon age $(1500-1000$ years B. P.), and fixed by the upper black humus.

The upper black humus is correlated to the younger humus sand definited by ENDo (1969). The upper part of Ishikari sand dunes are the present dunes.

1) 1973 年 11 月 9 日受付

2) 東京大学理学部地理学教室, Department of Geography, Faculty of Science, The University of Tokyo.

3) 日本大学交理学部 応用地学教室, Department of Applied Earth Sciences, College of Humanities and Sciences, Nihon University. 


\section{I. は じめに}

石狩低地帯の北西端に位置する石狩海岸平野に見られ る沖積世の砂質の諸地形，すなわち海岸側から内陸に向 けて帯状に分布する石狩砂丘地带・花畔砂堤列地带・紅 葉山砂丘地帯については, 石狩低地帯の地史を考える上 で一つの重要な鍵となる地域であり，従来より多数の人 々によって言及されてきた(第 1 図参照).たとえば，中 野 (1951), 北川ほか (1956), 阪口 (1961a b b c c), 大 島 (1969), 湊ほか (1972), 北川ほか (1973) 等がある.

北川ほか (1956) は各種洪積統, 沖積統の分布や性格 について記載し，特に紅葉山砂丘砂層の下部を構成する 砂碩層について言及している。阪口（1961 c ） は紅葉山 砂丘を境にして, 海岸側と内陸側で泥炭層の厚さが急变 するという事実を明らかにし，また，泥炭層の堆積開始 時期は 5000〜6000 年前と考えてよいこと, 石狩丘陵の 延長部にあたる 当地域は, その地下の浅い所に第三系 （材木沢泥層）およびこれをけずって形成された段丘堆 積物がもぐっていることを推定した.

大島（1969）は紅葉山砂丘の下部を構成する砂啋層に ついて再び注目し，多数のボーリング資料の解析を行な い，さらに石狩高岡の低位段丘（垣見，1958）崖下の繩 交時代の堅穴遺跡（海抜 $6 \mathrm{~m}$ ) についての考察から, 繩 文海進の最高海面高度は $6 \mathrm{~m}$ を越えなかったとし, 紅 葉山砂丘砂層は表層を除いて洪積統であると考えた.

北川ほか（1973）は, 本地域の沖積層を 4 区分し, 層 位·古生物学的な考察から, 沖積世における 2 回の海進 を主張した。

これらの研究は, 紅葉山砂丘や石狩泥炭地に重点がお かれ, 石狩砂丘や花畔砂堤列については多くはふれてい ない、したがって，筆者らの意図してきた日本島の海岸 砂丘地帯の地形発達史研究* の一環として, 石狩砂丘, 花畔砂堤列, 紅葉山砂丘の相互の関係を見るという方向 のものではなかった，筆者らは，従来明らかにされた資 料に, 砂質堆積物の粒度分析結果, 土壤層や沖積世火山 灰層を鍵層とした層位学的な調查結果, ${ }^{14} \mathrm{C}$ 年代測定值, 上野秀一氏**から, 提供された出士文化遺物の資料を加 え, 紅葉山砂丘地帯より海岸寄りの地域についての地形 発達史的検討を行なった.なお, 土壤層については, 上 述のように, 一種の地層単位として扱った. その意味で は，土壤学上の厳密な定義からはずれた記載の仕方にな っている簓所が多いことを最初にのべておきたい.

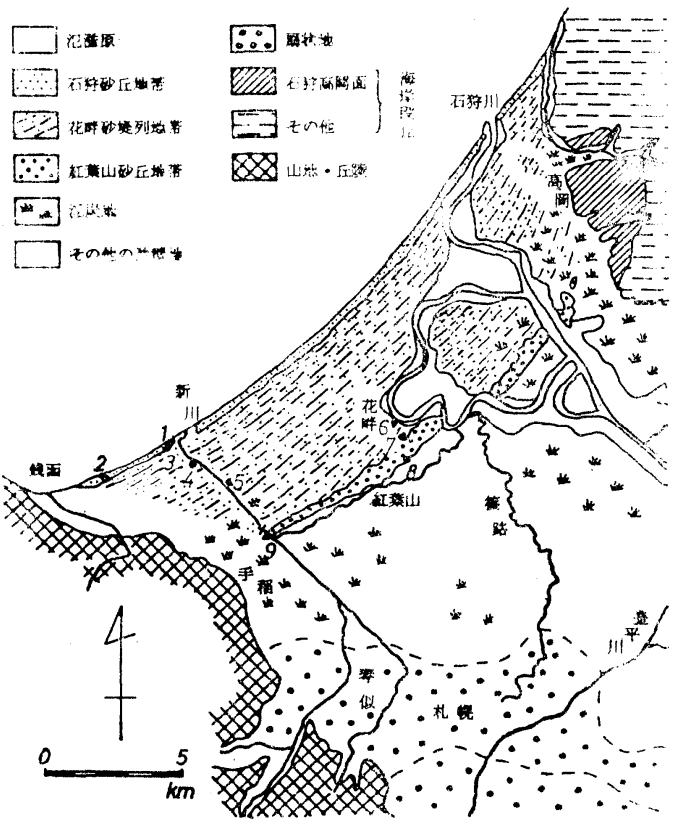

第 1 図 地 形 分 類図

- 印の数字は，第 2 図の柱状図番号と一致する. $\times$ 地点は年代測定試料採集地点（第 4 図）である。

\section{II. 石狩海岸平野の砂質諸地形}

石狩海岸平野は, 紅葉山砂丘より海岸奇りの砂丘 砂 堤地帯と, その内陸の泥炭地・扇状地帯とに大きく分か れる．本稿では, 前者を重点的にとりあげる．この砂丘． 砂堤地带は海岸寄りから形態的に, 石狩砂斥地带, 花畔 砂堤列地帯, 紅葉山砂丘地带の 3 地形区にわかれる.こ の形態的差異はその発達過程の違いを反映したものであ り, 以下，最も新しい石狩砂丘地帯から説明を加える.

\section{石狩砂丘地帯}

現在の海岸沿いに分布する北東部ほど幅が広い砂丘で あり(第 1 図)，垣見 (1958) による若干の記載がある. 北東部では砂丘列は $6 \sim 7$ 列に達する. 海岸側の 3 列は 八マナスに覆われ，土壤層は全く発達していないか，極 めて貧弱である. 一方, 内陸側の $3 \sim 4$ 列は密生する力 シワ林に覆われ，厚さ $5 \sim 30 \mathrm{~cm}$ の黑色の砂質腐植層が 分布する. この黒色層は一般にその下部ないしは直下 に，時により風成砂層をはさんで $1 \sim 2 \mathrm{~m}$ 下位に白色〜 灰黄色の厚さ $2 \mathrm{~cm}$ 前後の火山灰をレンズ状にともなう もので（第 2 図 1，2，3），当地域のより古い地形面を

* 遠藤 (1969), 遠藤 ·上杉 (1972)

** 札幌市教育委員会 
も広く覆って分布しているものである．以下，これを上 部黑土層と呼ぶ（第 2 図). 石狩砂丘は全層細粒〜中粒 砂層により構成され，上部黒土層によって上下に 2 区分 される.上部砂層は風成砂よりなり, 層厚 $5 \mathrm{~m}$ 以上で, ハマナスに覆われる石狩砂丘の海岸寄りの砂丘列の主た る構成層となっている。一部では，第 5 図にあるように 上部砂層が上部黒土層を覆うのが観察される：このハマ ナス砂丘をつくる上部砂層は現在の海岸線に対応する風 成砂であり，遠藤(1969)の新期砂丘 $\mathbb{I}(D y \mathbb{I})$ にたる. 下部砂層は風成砂を主とし，現在カシワ林となっている 砂丘列を構成している。層厚は $3 \mathrm{~m}$ 以上である・風成部 の下位の砂層は粒径頻度分布のタイプから海成と考えら れ，標高 $1 \sim 2 \mathrm{~m}$ 以下に分布している（第 2 図 3 , 第 3

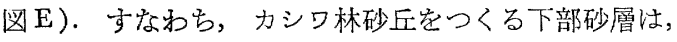
現在より $1 \sim 2 \mathrm{~m}$ 高い海面のもとでやや内陸側にあった 海岸線に 対応して形成された海成执よび風成砂層であ り，遠藤（1969）の新期砂丘 I (DyI) にあたる.

なお，上述の上部黒土層の下部ないし下位に存在する 火山灰層は, 内陸沖積低地の泥炭地では地表下的 $10 \mathrm{~cm}$ のところにはさま机，北川ほか(1956)，垣見 (1958) に より標前火山起源と推定されたものと同一であり，恐ら く, 山田 (1958) の Ta-a (1739 年降下) または Ta-b (1669 年降下) と考えられる．この火山灰層值下にも薄 く腐植層ぶ存在することがあり，下部砂層（DyI）の形 成期の上限は火山灰層の年代よりやや古くなりそうであ る.下部砂層の時代を直接示主資料は，も方あるせい が，全国的な傾向，あるいはオホーツク海沿岸常呂海岸 平野との対比（遠藤：1969，遠藤・上杉：1972）兄， また，後述するように，繩交晚期から続繩文期まで花畔 砂堤列地带から姿を消していた人類が擦交期に入ると再 び海側のカシワ林砂丘近くに現われるといった状況か ら，その時期を擦交の頃と予想している.

\section{花畔砂堤列地带}

花畔砂堤列地带は，標高 4 〜 6.5m で, おのおの幅 50 $\sim 100 \mathrm{~m}$, 比高 $1 \sim 2 \mathrm{~m}$ の 20 条学越元る砂堤列と砂堤間 低地とのくりか元しからなっている. 全体の幅は 3〜4 $\mathrm{km}$ に達し，3つの地形区のうち最も広い面積を占める (第 1 図・第 5 図). この砂堤列は上述の上部黑土層およ び火山灰層に広く覆われ，その下位に，黄褐·褐・暗褐 色の厚さ10〜30 cm の砂壤土が発達している（第2図 4 ・6). この砂壤土は，砂堤間低地ではうすい泥炭層〜泥 炭質黑色土壤に移行するか，あるいは泥炭層に覆われる 関係にあり，砂堤間低地へ向う斜面および低地内では漂
白されて灰白色を呈する（第 2 図 5 , 第 4 図). この土 壤層を上部黑土層に対して下部土壤層* と呼ぶことにす る. 下部土壤層の生成年代や性格については後に項它改 めて述べるが，花畔砂堤列地帯にあっては，繩交中期後 半（約 4000 年前）には土壤生成が始まっていたと考え られる。

花畔砂堤列の最内陸部に位置する新川中央橋付近の砂 堤列間低地(第 1 図 9)には泥炭層が分布し, この泥炭層 の下位は最上部が漂白された赤褐〜黄褐色風化砂層で, 下部土壤層に相当する (第4 図). この風化砂層は高度

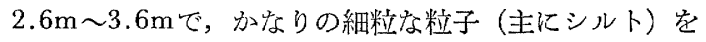
含えでおり，海岸側へ綏く傾斜する平行なラミナの発達 した砂層に連続する.この砂層は粒径頻度分布のタイプ から，内湾の汀線に近い浅海堆積物と考えられる（第 3 図 $\mathrm{G})$. この砂層は, さらに, 新川に沿って河口側へ連 続しており, 河口から約 $2 \mathrm{~km}$ 内陸の砂堤の表面下 $2 \mathrm{~m}$ (標高 $4 \mathrm{~m}$ 弱) の砂層も浅海型を示した（第 3 図 $\mathrm{F}$ ). こ れらの点から, 花畔砂堤列構成砂層はその汪とえどが海 成であり，風成砂層は全地域にわたりきわめてうすく， 厚いところでも $1 \sim 2 \mathrm{~m}$ 程度と考えられる.すなわち， 花畔砂堤列地带は繩交海進の極相期の $3 \sim 4 \mathrm{~m}$ の海面高 度のもとで浅海底に堆積し, 繩交中期以後次々と離水し たもので，陸化してもこの時期が遠藤（1969）のいう砂 丘の固定期にあたるため，風成砂の堆積をほとえどみな かった. 赤松 (1972) は，この地帯で標高 $3 \mathrm{~m}$ の浅海性 の自然貝殼層を発見した.この高度や，暖流性の貝類を 含むことは，上記の推論と矛盾しない。

なお，花畔砂堤列は，石狩川北岸の石狩高岡段丘に隣 接する生振平野では砂堤間低地だけでなく砂堤列そのも のも泥炭層によって覆われている. 泥炭層の厚さは約 3 $\mathrm{m}$ 弱に達している.

\section{紅葉山砂丘地帯}

紅葉山砂丘地带は生振・紅葉山・砂山などを連ね， 5 〜20mの高度をもって長くのびる. 砂丘帯の幅は全般に 0.5〜 $1 \mathrm{~km}$ であるが，南西の砂山付近では 内陸側が河 川の蛇行により削られて狭くなり，手稲付近ではみられ なくなる (第 1 図). 個々の砂丘は, 紅葉山砂丘全体の 一般方向に対してほぼ直交する北西・南東方向に長軸を もち，不規則に並えだ細長い馬蹄形砂丘で，一種の縦列 砂丘といえる. 砂丘は，下位の高度 $4 \mathrm{~m}$ 強までの円砅層 およびラミナの見られる細砂層とその上位の風成砂層と を構成層としている（第 2 図 7，8，9）。 円碩層につい てはすでに北川ほか（1956）が言及し，砂丘带に沿って

* 下部土壤層は, 北川汸 (1956) の花畔砂壤土にあたる. 


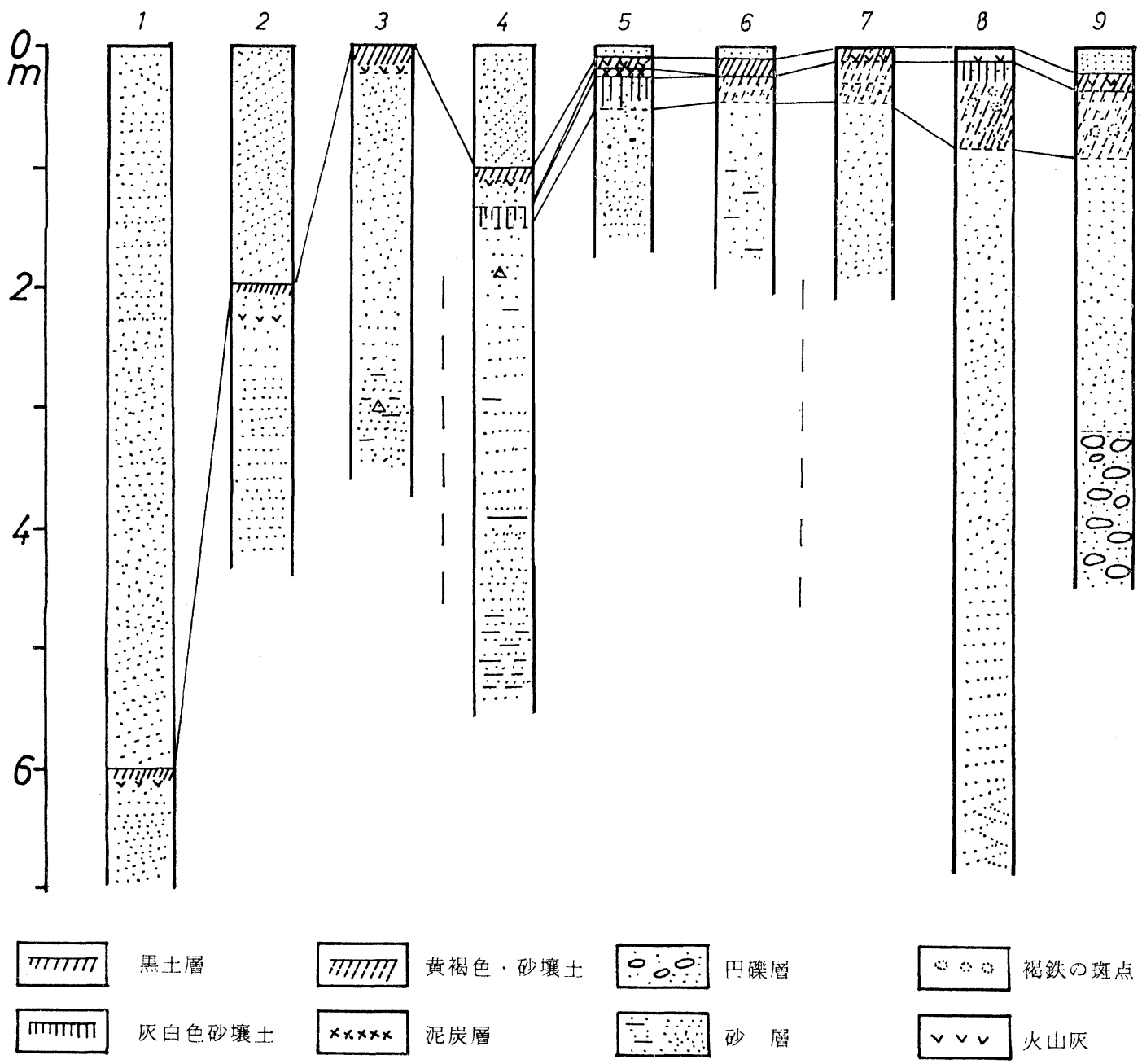

第 2 図地質柱状図

1 : 新川河口； 2 : 銭函大浜； 3 : 新川河口より $300 \mathrm{~m} ; 4:$ 新川河口より $2 \mathrm{~km} ; 5:$ 新川河口より

$4 \mathrm{~km} ; 6:$ 花畔; $7:$ 上花; $8:$ 上花；9: 砂山. 柱状図番号は第 1 図の地点番号と一致する.

$\triangle$ 粒度分析試料.

その延長方向に幅 $50 \sim 100 \mathrm{~m}$ ，檿さ $2 \mathrm{~m}$ 余で分布し，礫 は扁平で，海岸に見られるものと類似することが知られ ている・この円礫層に連続すると思われるラミナの見ら れる細砂層はその上位の風成砂層とは異なり，粒径頻度 分布のタイプは，上杉（1972）によれば海成を示してい る(第 3 図H，I，J)。この円礫層*および細砂層は繩文 海進極相期のものと考无るが，恐らく，その分布から， 主体は䃯州として堆積したものであろう. 円䃯層・細砂
層の下位にはかなり浅い場所に阪口（1961 c ）のいう洪 積層ぶくるものと思われる，風成砂層は西端の砂山地区 ではうすいが，一般に層厚 $5 \mathrm{~m}$ 以上に達する場所が多く， 最大 $15 \mathrm{~m}$ に達している.

砂丘表面の土壤層は花畔砂堤列と同じで，上部黒土層 および下部土壤層で構成される。ただ，下部土壤層は一 般に花畔砂堤列の場合に比較して厚く, 後述するように 厚さ $50 \mathrm{~cm}$ をこ光，土壤断面の層位分化のはっきりして

* 円䃯層が海成であるという確実な証拠があるわけではない。なお，北川ほか (1973) の暖流系貝類を産する前田 砂層・生振砂䃯層とこの円碰層との関係は明らかでない. 

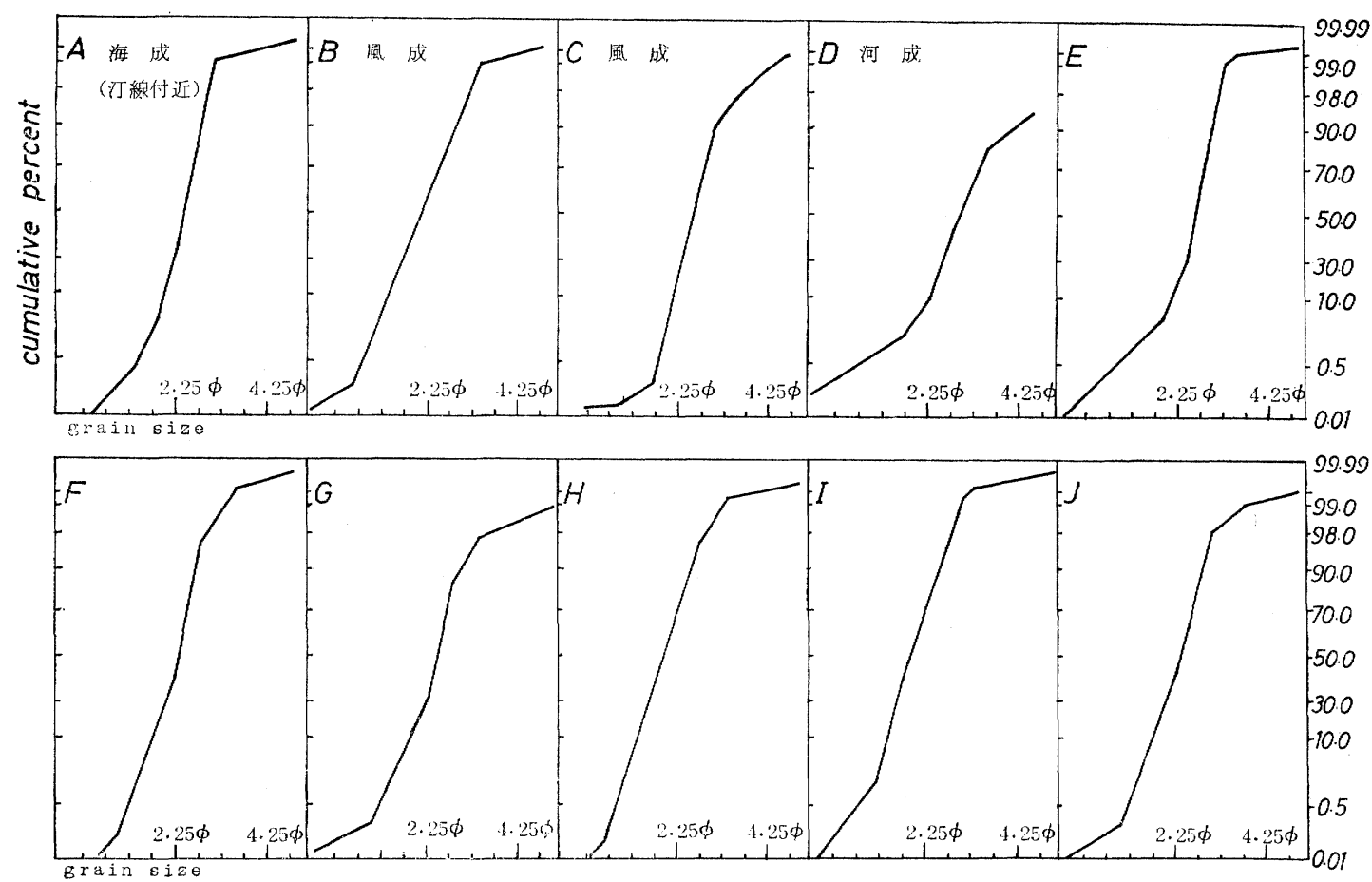

第 3 図 現生乱よび古期の砂質堆積物の䊀径頻度分布

$\mathrm{A}$ ：新川南方 $2 \mathrm{~km}$ 汀線砂 (海成)； $\mathrm{B}$ : 花畔 5 線現生砂丘砂（風成）， $\mathrm{C}$ : 山口, 石狩川河畔砂丘 砂 (風成); $\mathrm{D}$ : 石狩川, 豊平川合流点河床砂 (河成); $\mathrm{E}$ : 新川河口上り $300 \mathrm{~m}$ 内陸, 石狩砂丘下 部, 高度約 $1 \mathrm{~m}$, 汀線に近い海成砂と考元られる. (柱状図番号 3 ); F : 新川河口より $2 \mathrm{~km}$ 内陸, 花畔砂堤列の地表下 $2 \mathrm{~m}$, 高度約 $4 \mathrm{~m}$ 弱. 汀線に近い海成砂と考元られる. (柱状図番号 4 ); G : 新川河口より約 $5 \mathrm{~km}$ 内陸の新川中央橋脇. 年代測定試料採集地点 (第 4 因参照). 花畔砂堤列の 最奥部砂堤間低地の泥炭層下の風化砂層, 高度 $3 \mathrm{~m}$. 内湾の弱エネルギー下での汀線に近い浅海砂 と思われる; $\mathrm{H}$ : 上花, 紅菜山砂丘砂. 表面下 $4 \mathrm{~m}$, 高度 $6 \mathrm{~m}$ 前後. 典型的な風成砂である; I : 生振, 紅葉山砂丘砂. 表面下 $2 \mathrm{~m}$, 高度 $6 \mathrm{~m}$ 前後. 典型的な風成砂; $\mathrm{J}:$ 上花, 紅葉山砂丘間低地 の水平なラミナの発達する砂丘層. 高度 $4 \mathrm{~m}$ 強. 汀線に近い海成砂と思われる.

いる場所もある.

下部土壤層は遠藤（1969）の旧期クロスナ層(Ho)に， 風成砂は旧期砂丘砂（Do）に対応卞る。

\section{III. 下部土壤層}

花畔砂堤列および紅葉山砂丘のいずれにも発達してい る下部土壤層は, 砂丘や砂堤の頂部, その斜面, それら の間の品地等の位置によって性格を異にしている.すな わち, 紅葉山砂丘地带では, 下部土壤層は砂丘表層部に 発達しており，層位学的には砂丘を直接覆っているとい えるが，砂丘頂部では褐色ローム質土墥（砂壤土）であ ることが多く, 一部では暗褐色腐植質土壤に移り変って
いる. 斜面では漂白されており, 一部では灰白色溶脱層 とその下位の褐色斑紋状集積層の明瞭なポドゾール性土 埕断面*が観察される（第 1 図および第 2 図の 8 ). この 灰白色部は凹地の縁辺部まで続き，泥炭層につながった り，泥炭層の下にもぐりこんだりする。なお，凹地では 泥炭層の下に，局部的に褐鉄鉱層が発達することがあ る.

以上のような下部土壤層の産状は花畔砂堤列でもほぼ 同様である。ただ，紅葉山砂丘に比較し，下部上壤層の 厚さがうすく，より未成熟な土壌断面を示すといえる.

下部土壤層の形成年代に関してはいくつかの資料があ る.上野秀一 $(1967,1968)$ および最近の上野秀一・木

* 北川ほか (1956) はポドゾール化作用の可能性を指摘している. 


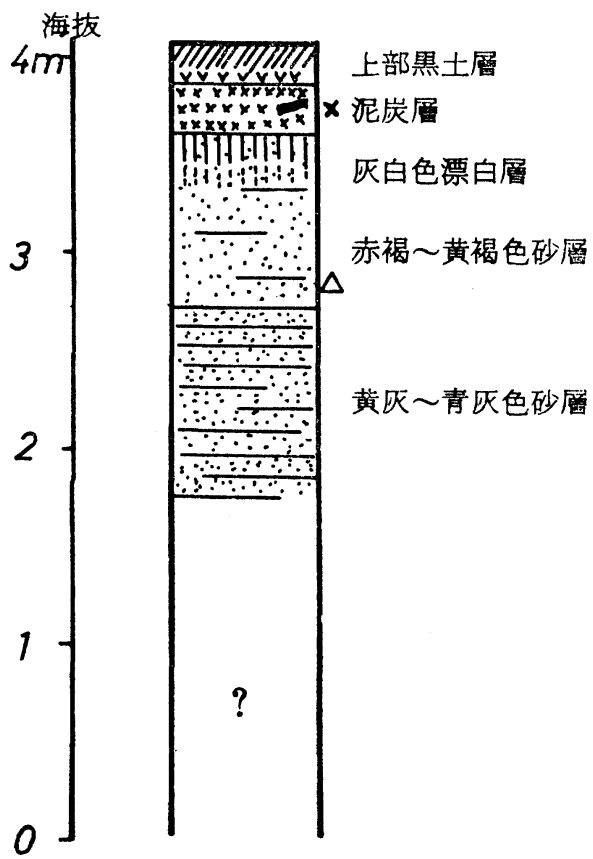

第 4 図年代測定試料採集地点の地質柱状図 位置は第 1 図の $\times$ 印地点, $\times$ 年代測定試料, $\triangle$ 粒 度分析試料.

村英明* 両氏からの私信によると，花畔砂堤列地带・紅 葉山砂丘地帯の遺物包含層は下部土壤層に限られ，現在 までのところ花畔砂堤列地带では繩文中期後半以降の常 呂 6 相当 ·伊達山・富川式から繩交後期の御殿山式まで 乙擦文式の土器片が，また紅葉山砂丘地帯では繩交中期 初期のサイベ沢 $\mathrm{V}$ 式にはじまり後期・晚期・続繩交およ び土師などの土器が発見できるという。

花畔砂堤列地帯では, 繩交晚期・続繩文期の遺物が発 見されず, 紅葉山砂丘地帯では続繩交期の遺物が大量に 発見されるという傾向があるようである。これらの資料 から, 紅葉山砂丘地带よりも花畔砂堤列地带の方が下部 土壤層の生成はやや遅れて（吉崎（1965）の編年によれ ば，土器形式に二形式の差がある）開始されたと考えた W**.

筆者らは，花畔砂堤列の最内陸部に位置する新川中央 橋付近の砂堤間低地の泥炭層中から木片を採集した（第 4 図). この木片は上部黒土層に覆われた泥炭層の最下
部に含まれ，その ${ }^{14} \mathrm{C}$ 年代は $3230 \pm 100$ 年 B.P. (GaK4207）の值を示した. この值は砂堤間低地の泥炭の堆積 開始年代を示している。この值は，泥炭の堆積速度を年 $1 \mathrm{~mm}$ と仮定すれば，花畔砂堤列地帯の北部(生振原野) の砂堤頂部までを覆う泥炭層の厚さ, 約 $3 \mathrm{~m}$ といら值と 良く調和している。これらの資料から，花畔砂堤列地帯 で泥炭の堆積が始まったのは紅葉山砂丘より内陸の各泥 炭地より 2000 3000 年遅れて, 約 3000 3500 年前の 繩交晚期からといえよう。

繩交晚期は，阪口（1961 b ), 安田（1973）, 五十嵐・ 熊野（1973）のいう気候の泠涼・湿潤化の時期にあたっ ている. この時期に，少くとも繩文中期後半（約 4000 年前）から約 1000 年にわたり, 離水した砂堤列の上で 生活していた繩文人は，周辺で泥炭層が形成されだすと いう居住・生活条件の悪化を一つのきっかけとして花畔 砂堤列地带から後退し，擦交期に入り再び進出したので あろう。

下部土壤層の最上部がとくに砂堤間低地へ向う斜面で 灰白色となりポドゾール化作用を受けたことが推定され る. この点と上述の資料から，筆者らは，下部土壤層は 多元土壤であると考元た.

すなわち，沖積世の海面高頂期の末期頃（繩交中期初 頭）から紅葉山砂丘地带では下部土壤の生成が始まった が，まだ比較的温暖な気候のもとで褐色ローム質土壤ま たは暗褐色腐植土が形成された. 続いて花畔砂堤列も陸 化し，ほぼ同様な気候環境下で同様な土壤生成が開始さ れた. その後，3000～3500 年前頃（繩文晚期）から気 候が冷涼・湿潤化し，下部土壤層はポドゾール化作用を 受けるようになった. 特にこれは砂丘や砂堤の斜面にお いて顕著であった。

\section{IV. 花畔砂堤列と紅葉山砂丘との関係}

紅葉山砂丘地带の海成層の高度は，すでにのべたよう に, 粒度分析結果から $4 \mathrm{~m}$ 強と推定され, 花畔砂堤列地 带の最も内陸側に拈ける海成層の高度と大差ないもので ある. 紅葉山砂丘地带には厚い風成砂が見られるのに対 して，花畔砂堤列地帯には風成砂はほとえど見られな い, 両者ともに下部土壤層が発達しているが, 紅葉山砂 丘地帯の方が土壤生成の開始がやや早い，両者の間には 泥炭層の発達する凹地があって, 紅葉山砂丘の風成砂は

* 札幌大学文化交流研究所.

** 土器およびその包含層の堆積した時代は，一般には土壤化の時代と一致するとは限らない。しかし，全国的に 分布する旧期クロスナ層の腐植の ${ }^{14} \mathrm{C}$ 年代測定值とクロスナ層に包含される土器の時代との一致などから，包 含される土器が土壤生成期を近似すると考えてょいと思われる。 


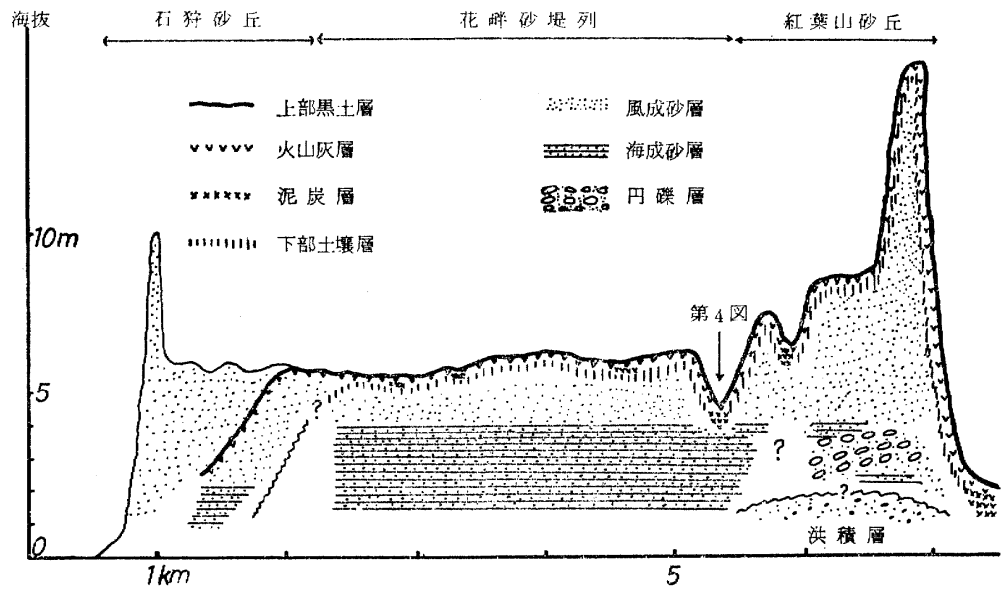

第 5 図石狩海岸地質断面概念図

この回地境に花畔砂堤列側に連続しない.しかし，上 花近辺のように花畔砂堤列の最奥部の $2 \sim 3$ 条が，海側 に高度を下げながら張りだしてきた紅葉山砂丘によって 覆われているところもある。

以上のような特徵を示す紅葉山の海成層・風成層, 花 畔砂堤列を構成する海成層の堆積過程については次のよ うな幾通りかの考えが成り立つ.

1）洪積世末には紅葉山砂丘は形成されていて，繩交 海進の時にはこれが barrier となり，前縁に花畔砂堤列 が形成される。

2）紅葉山砂丘の海成層は繩文海進の高頂期に形成さ れたが，その後に海退をはさんで再び海進があって，花 畔砂堤列が形成された。この時の海岸線は同砂堤列の最 も内側にあり, その後の海退で砂堤は次々と陸化した.

3) 紅葉山海成層を堆積させた繩文海進の高頂期の 後, 穏やかな海面低下があり, 紅葉山風成層の堆積と花 畔砂堤列の形成・陸化が行なわれた.

これらのうち，1）の考えは大島（1969）の論文に代 表されるが*，周辺の洪積段丘に見られる褐色風化火山 灰層が発見されないなど，紅葉山砂丘を洪積統とする根 拠が十分でなく，さらに紅葉山砂丘の発達史上の位置づ けが困難である.この考えに従うと，繩交海進の際に紅 葉山砂丘はその海側を海食により破壊され，連続した直 線的な汀線地形がその前縁に残されると同時に，紅葉山 砂丘地带内の洪積統の上に不整合で沖積世の風成砂層が のることになるが，筆者らはそのような地形やあるいは 露頭を発見できなかった。

2）については, 紅葉山砂丘と花畔砂堤列との境界か
必らずしもきれいに引けず，2 度目の海進時の汀線地形 が残されていないなどの難点がある。なお，北川ほか (1973) 范地域の沖積層の層位学的. 古生物学的考察 から, 沖積世に和ける 2 回の海進を主張したことはすで に述べたが，上述の 2 つの地形区との関連については記 載がないのでここでは言及しない.

筆者らは, 現在の資料から 3) の考光が最も妥当なも のであると考えている，それによると，下部土壤層の生 成に到る発達史は次のとおりである.

繩交海進の高頂期（繩文前期）飞紅葉山砂丘の海成層 (円礫層とその上位の細砂層) が堆積した. 汀線のゆる やかな前進とともに, 陸化した紅葉山砂丘の海成層の上 位に風成砂が堆積し, 沖合には偽層の発達した浅海砂層 が堆積していった. 繩文中期の初期には, 紅葉山砂丘は すでに横列砂丘から縦列砂丘に变形しており, 植生によ って固定され下部土壤層の生成が開始されていた・繩文 中期の後半には, 花畔砂堤列の大半は遺物の分布から考 えてすでに離水しており，下部土壤層の生成がすでに開 始されていた。

筆者らは，上述のように繩交海進の高頂期を繩文前期 としか述べることができなかった・すでに大島（1969） は石狩高岡の低位段丘崖下の遺跡 (高度 $6 \mathrm{~m}$ ) 汃ら発見 された静内中野式土器を繩交早期末葉のものとし，繩交 海進の高頂期はこの時期ないしはとれ以前であるとして いる. 静内中野式の時期については吉崎 (1965) が繩文 前期としているように，乙れを早期とする見解は少ない ようである.この遺跡は繩文海進時に形成された波食棚 上に立地するように思われるが，乙れを根拠に，当地域

\footnotetext{
*最近，大島はその考えを変えた。
} 
の繩文海進の高頂期が静内中野式土器の時代ないしはそ れ以前とするにあたっては，たとえば，この地形がスト ーム・ベンチのような海面上かなり高い位置に形成され たものでないかどらかといった，より䂭密な地形学的検 討が必要とされよう。

\section{v. と め}

1）筆者らは下部土壤層について，いくつかの異なっ た環境の下での土壤生成作用をうけた多元土壤であると いう立場をとった・この土壤はとの生成時代から，全国 的に観察される旧期クロスナ層（遠藤，1969）に対比さ れるものである.下部土壤層は灰白色の溶脱層および褐 色の集積層で示されるポドゾール化作用を受けたことを 意味する断面を持っていたり，あるいは暗褐色の腐植層 となっていたりするが，このような土壤の産状は北海道 では石狩海岸のほかに浜頓別や常吕海岸で 観察するこ とができる．道南および東北地方以南では，黑色腐植土 (クロスナ層, クロツチ層) となっており, 上述のよう な土壤断面は観察されない*.

サロベツや礼交島の砂丘帯における旧期クロスナ層相 当層は，道南のそれに比べ腐植の集積が弱く，褐色をお びている. すなわち, 岩内以南の道南砂丘地帯と石狩海 岸平野以北の，サロベツ，礼交島，声問，浜頓別，常呂 等の各砂丘地帯とでは，旧期クロスナ層相当の土壤層の 性格において明瞭な差を認めることができる．このこと は繩文中期〜晚期に至る砂丘地における土壤生成が気候 帯の差異に基づく影響をらけたことを物語る。

2）繩文前期頃の繩文海進の海面高頂期頃に，紅葉山 砂丘の母体をなす海成層が堆積し, 続いて風成砂が累積 していった. 常呂砂丘のように沖積世砂丘の基盤に洪積 世末期の低位段丘が確認できる場合もあるが，かりに紅 葉山砂丘地帯で同時期のものがあるとすれば，支第や恵 庭などの噴出物に覆われているであろう。ここでは，阪 口（1961 c ）のいらように洪積統は海蝕により削られ， 円碩層の更に下，比較的浅いところにかくれているもの と思われる**.

3）石狩海岸平野の地形的特徵の 1 つは，広く砂丘の ほとんど発達しない花畔砂堤列である. 広い砂堤列を はさんで内陸側と海岸側に砂丘が発達する砂丘地帯とし ては干葉県九十九里浜があげられるが，そのほか，サロ ベツ海岸砂丘地帯, 新潟砂丘地帯のように幅広い砂丘列
をなす砂丘地帯は大なり小なり同様な傾向を示す.これ に対して砂丘列をなさない砂丘地帯では, 砂堤列を欠い て, 新・旧砂丘が直接おり重なっている. 砂堤列は繩交 海進が海退に転じた時に次々と浅海底が陸化してできた もので，その離水の時期はすでに砂丘の固定期に入って いた. 石狩のような浜堤列を伴うタイプの砂丘地带は, 洪積世末期に現沖積面に近い高度で広い海成面ないしは 河成面が形成され，しかも繩交海進後の稳やかな海退に よって広大な浅海底が陸化しうるような地域であって， 大河川の河口部などに多いように思われる。しかし，全 国に広く認められるこのようなタイプの砂丘地帯の中核 をなす浜堤列そのものの形成史については，未だ不明な 点が多い.たとえば, 浜堤列は海底のbar 群が単純に離 水したものとは考えにくいが，ではどのような海面変動 のタイプのもとで浜堤列に変化するのか, あるいは, 浜 堤列を構成する莫大な量の砂は海面高頂期にはどのよう な状況のもとにあったのか, その砂丘形成との関係はど うなのかといった問題がある.

4) 泥炭層は, 花畔砂堤列地帯では気候の悪化期（約 3000 年前）に形成されている. 一方, 阪口 (1961a，c) によると紅葉山砂丘より内陸の各泥炭地では5000 6000 年前に泥炭の堆積が始まっている. 本稿では, この両者 が性格を異にするものかどうか検討しえなかった。

5）繩文後・晚期頃以来の小海進が，擦文の頃，小海 進に転ずると推定した．繩文後期から弥生にかけてやや 低下していた海面が，古墳時代に現海面近くに回復する という北陸地方の例（藤，1971）をはじめ, 砂丘地帯で は 1500〜1000 年前頃に小海進ないし新砂丘の形成のみ られる地域が多い. 擦文であればこの時代とよく符合す るが，直接的資料がないので正確にはいえない，花畔砂 堤列を切る石狩川汇濫原は一部段化しているが，この部 分からは明確な遺跡あるいは鍵層を発見していない。も しこの部分から何らかの年代資料を得ることができれば 石狩川がいつ花畔砂堤列を切る現河道をとることになっ たかが明確になるばかりでなく，石狩砂丘の下部砂層の 形成期についても間接的に何らかの知見が得られる筈で ある・

6）上部黒土層はかならず樽前火山灰 Ta-a あるいは Ta-b と思われる火山灰を伴っているが，同火山の降下 時にはある程度土壤形成が進えでいたと思われ，同火山 灰の降下堆積によって砂丘が固定化し土壤生成が始まっ

* 重粘地グループ (1967) によれば，北海道北部では，成帯性のポドゾル性土壤が広く分布する.

** 最近, 湊・藤原・熊野 (1972) は, 北海道の海岸平野における軟弱地盤の深度に関する論交を発表しているが, この論文では，紅葉山砂丘地帯にあってはいわゆる沖積層の基底が，全域にわたり媣い位置に描かれている。 
第 1 表 石狩海岸平野地形発達編年表

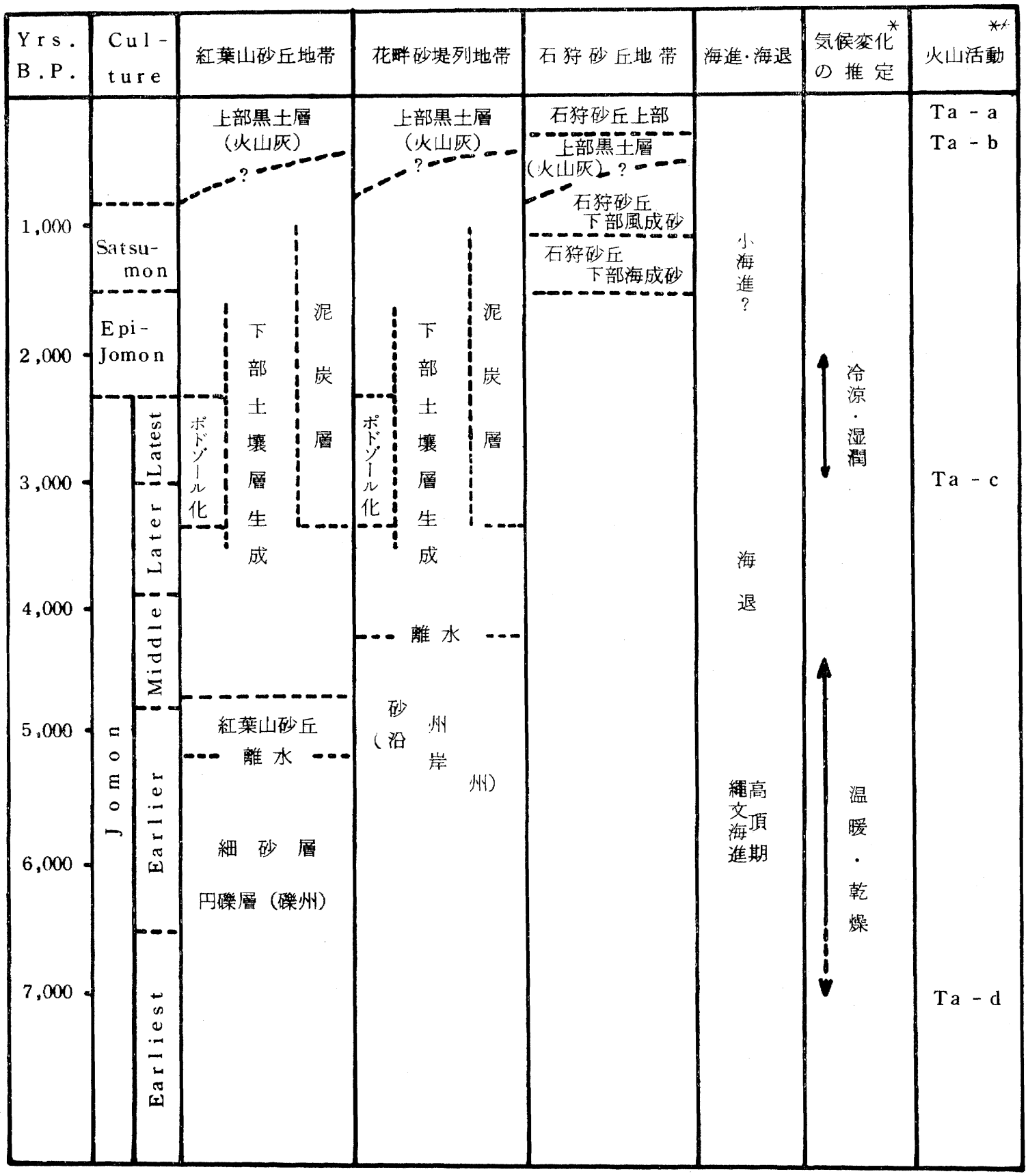

* 阪口（1961b），安田（1973），五十嵐・斯野（1973）に上る。

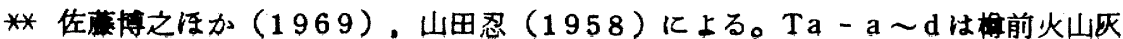


たとはいえない，

\section{謝 辞}

この論交を書くにあたって, 東京大学理学部地理学教 室の阪口豊助教授には原稿を読えでいただき，多々御教 示を賜わった・札幌市教育委員会の上野秀一氏には考古 資料を提供していただき，さらに札幌大学交化交流研究 所の木村英明講師には現地を案内していただくなど様々 な便宜をはかっていただいた，学習院大学木越邦彦教授 には年代測定をお願いした。また，丸中建設の諸氏には 年代測定試料採集地点の高度測定をしていただいた。

これらの方々に深く感謝いたします.

\section{引用交 献}

赤松守雄 (1972) 石狩川河口付近の自然貝殼層. 地質雑, 78 (5)，275-276.

遠藤邦彦（1969）日本における沖積世の砂丘の形成につ いて. 地理評, 42 (3), 159-163.

遠藤邦彦・上杉 陽 (1972) オホーツク海沿岸トコロ海 岸平野の地形・地質. 東京大学交学部考古学教室編 [北海道サロマ湖沿岸・常呂川下流域における遺跡調 查], $493-504$.

藤 則雄 (1971) 北陸の海岸砂丘の埋積腐植土層の編年 とその生成環境. 第四紀研究, 10 (3)，134-146.

五十嵐八枝子・熊野純男 (1973) 湧別市川遺跡周辺に打 ける沖積世の古気候变遷. 演別市川遺跡調査団・湧別 町教育委員会編, 涌別市川遺跡, 99-106.

重粘地グルーブ (1967) 北海道北部の土壤. 195 pp., 北 海道開発局.

垣見俊弘 (1958) 五万分の一地質図幅「石狩」，および 同説明書. 地質調査所.

北川芳男・小山内熙・杉本良也 (1956) 五万分の一地質 眓幅「札幌」，および同説明書，北海道立地下資源調 查所.

北川芳男 · 赤松守雄 · 平川善祥 · 熊野純男 · 五十嵐八枝 子 (1973) 石狩低地帯の後水期の变遷. 日本第四紀学
会 1973 年度総会研究発表要旨, 第四紀研究, 12 (1), 2.5 .

湊 正雄 - 藤原嘉樹 - 熊野純男 (1972) 北海道の海岸平 野における軟弱地盤の哚度. 地質学論集, (7), 1-11. 中野尊正 (1951) 北海道の海岸低地. 地理評, 24 (8), $11-19$.

大島和雄 (1969) 紅葉山砂丘形成についての一考察. 地 質調査所北海道支所調查研究報告会講演要旨録, (20), $11-18$.

Sakaguchi, Y. (1961a) Paleogeographical studies of peat bogs in northern Japan. Jour. Fac. Sci. Univ. Tokyo, sec. II, 7 (3), 421-513.

阪口 豊 $(1961 \mathrm{~b})$ 北日本の完新世の気假変化. 地理評 34, $259-268$.

阪口 豊 (1961 c) 石狩川下流部の地形発達. 科学技術 庁資源局資料第 37 号, 石狩川泥炭地域の地形と水害, $33-40$.

佐藤博之 - 竹田輝雄 - 曾屋龍典 - 対馬坤六 - 山口昇一 （1969）樽前火山灰 G 層の降下年代について．地質調 查所北海道支所調査報告会講演要旨録，(20)，5-9.

上野秀一 (1967) 石狩砂丘遺跡の繩交中期土器編年. 歴 研月報, 14 (75), 12-14, 山形大学教育学部歴史学 研究会・山教史学会.

上野秀一 (1968) 石狩砂丘遺跡について. 歴研月報, 15 (81), 16-19, 山形大学教育学部歴史学研究会・山教 客学会.

上杉陽 (1972) 粒径頻度分布からみた風成砂・海成砂 の諸特徵. 第四紀研究，11 (2)，49-60.

安田喜害 (1973) 東北地方における後氷期後半の気候変 化. 地理評, 46 (2), 107-115.

山田 忍 (1958) 火山噴出物の堆積状態から見た沖積世 における北海道火山の火山活動に関する研究. 地団研 専報, (8).

吉崎昌一 (1965) 繩文文化の発展と地域性, 北海道.

[鎌木義昌編, 日本の考古学 II, 繩交時代, 462 pp., 河 出書房, 東京], pp. 30-63. 